\title{
Soren Kierkegaards gennemslag i den eksistentielle og humanistiske psykologi, psykoterapi og psykiatri
}

Det er de færreste ubekendt, at Søren Kierkegaard hører til blandt de mest indflydelsesrige danske tænkere, og at hans forfatterskab spænder bredt fra skønlitteratur til filosofi og teologi. Det er også mange bekendt, at Kierkegaards forfatterskab har inspireret forskellige receptioner og arvtagere inden for netop litteratur, filosofi og teologi. Derimod har der været mindre opmærksomhed på Kierkegaards psykologiske tanker og endnu mindre på den indflydelse, som Kierkegaards forfatterskab har haft på psyfagene, forstået som den moderne psykologi, psykoterapi og psykiatri. Min hensigt i denne artikel er at forfølge et særligt spor i denne indflydelse.

Ser vi på Kierkegaards egne psykologiske tanker, spiller de en nødvendig rolle i forfatterskabet for forståelsen af den menneskelige eksistens, og de psykologiske temaer indgår på forskellig vis i mere overordnede filosofiske og teologiske overvejelser. Kierkegaards psykologiske tanker modsvarer altså ikke den moderne psykologi som en selvstændig og afgrænset videnskabelig disciplin, og de slægter endnu mindre den moderne psykoterapi og psykiatri på. I den forbindelse må det bemærkes, at Kierkegaard udfolder sit forfatterskab på et historisk tidspunkt, hvor psykologien i det væsentlige endnu enten indgår som sjælelære i teologien eller er en underdisciplin af filosofien, mens psykiatrien stadig er nært knyttet til filosofien, og den moderne psykoterapi kun er i sin spæde vorden. Det er reelt ikke førend 1870erne, at psykologien bliver løsrevet fra teologien samt filosofien og for alvor bliver en selvstændig moderne empirisk videnskab (Saugstad 1998: 97). Selv om den moderne psykoterapi allerede har haft sin spæde debut i 1790erne, får den endvidere først sit egentlige gennembrud med Sigmund Freuds lancering af psykoanalysen fra 1890erne (Norcross 2011: 
3; Sørensen 2012: 118). Til gengæld er den moderne psykiatri blevet fuldt etableret som lægevidenskabelig disciplin på Kierkegaards tid i begyndelsen af 1800-tallet. Modsat i dag er datidens psykiatri dog præget af et tæt forhold til filosofien, og det er almindeligt, at filosoffer udgiver omfattende fremstillinger af sindssygdommene (Mellergård 2000: 33).

Kierkegaards psykologiske tanker er desuden blevet gjort til selvstændig genstand for en række forskelligartede studier, der har forsøgt at præsentere Kierkegaards tænkning i en psykologisk form eller udkrystallisere en sammenhængende psykologisk teori $\mathrm{i}$ moderne forstand fra Kierkegaards forfatterskab og psykologiske tanker (f.eks. Ostenfeld 1933; Künzli 1948; Lomholt 1959; Nordentoft 1995; Ferguson 1994; Evans 1995). Samtidig erkender Kresten Nordentoft i forordet til sin monumentale doktorafhandling Kierkegaards psykologi fra 1972, at en sådan bestræbelse på sin vis er et umuligt forehavende, idet Kierkegaards psykologiske tanker er "indfældet i et netværk af andre problemer" (Nordentoft 1995: 14).

Personen Kierkegaard er også blevet ivrigt undersøgt som klinisk case i psyfagene. Allerede i 1845 udgav litteraturkritikeren Peter L. Møller en anmeldelse, hvori han beskrev Kierkegaards forfatterskab som personlig terapi (Møller 1846). Især fra begyndelsen af det 20. århundrede og frem har adskillige psykologer, psykiatere og terapeuter forsøgt at reducere Kierkegaards forfatterskab til et udtryk for en psykisk lidelse (se f.eks. Grimault 1965).

Desuden har en del forfattere forsøgt at lave forskelligartede koblinger mellem Kierkegaards forfatterskab og psykoanalysen, herunder psykoanalyser af Kierkegaard (f.eks. Næsgård 1950). I de senere år har disse forsøg især taget udgangspunkt i den franske psykoanalytiker Jacques Lacan (f.eks. Rodolphe 2005).

Endelig har Kierkegaards forfatterskab fået et mere anvendelsesorienteret efterspil i forbindelse med udviklingen af henholdsvis den eksistentielle og den humanistiske psykologi, psykoterapi og psykiatri. Kierkegaards eget opbyggelige formål med sit forfatterskab er ikke den anskuelse, der kan opnås gennem lærde og objektive svar på de fundamentale spørgsmål, som Kierkegaard stiller, men derimod det virksomme $i$ at omskabe hele tilværelsen for læseren (SKS 16: 20). I samme ånd vil jeg i artiklen også undersøge, hvordan Kierkegaards tanker er blevet anvendt i den eksistentielle 
og humanistiske psykologis og terapis ærinde i forhold til at forstå og omskabe tilværelsen for mennesker. En sådan forfølgelse er tiltrængt. Særligt inden for den eksistentielle tilgang har Kierkegaard længe stået i skyggen af især den tyske filosof Martin Heidegger, og Kierkegaards indflydelse på den eksistentielle psykologi og terapi er i det væsentlige blevet negligeret. Der er endnu ikke udfoldet nogen sammenhængende behandling af Kierkegaards gennemslag i den eksistentielle og humanistiske psykologi, psykoterapi og psykiatri. Den eksistentielle og humanistiske tilgang omfatter to nært beslægtede tilgange til psyfagene, der siden henholdsvis 1930erne og 1940erne har benyttet indsigter og principper fra eksistensfilosofien og eksistensfænomenologien som armering i et opgør med naturvidenskabelige og teknologiske tilgange (Cooper 2011). Som alternativ advokerer repræsentanterne for både den eksistentielle og humanistiske tilgang til psyfagene for en eksistentielt og humanistisk formidlet vækning af feltet, der trækker på humanvidenskabelige og filosofiske metoder og færdigheder. I den forbindelse optræder Kierkegaard blot som en blandt flere inspirationskilder, der har givet ammunition til reformbestræbelserne. I dette spil trækker de eksistentielle og humanistiske psykologer, psykiatere og psykoterapeuter samtidig ikke så meget på Kierkegaards idéer ud fra en eksegetisk erkendelsesinteresse $i$ at fortolke og udlægge hans forfatterskab på en uomtvistelig eller fyldestgørende måde. Deres udlægning af Kierkegaard er derfor heller ikke båret af den troskab over for forfatterskabets terminologi og andægtighed over for værkernes detaljer, som ofte præger receptionen af den danske tænker. Tværtimod inddrages Kierkegaards greb og tanker ud fra en rent anvendelsesorienteret erkendelses- og praksisinteresse i muligheden for at kunne gøre brug af dem til en mere helhedsorienteret tilgang til menneskets konkrete eksistens og iboende potentialer.

I sine egne skrifter benytter Kierkegaard sig af litterære figurer og gendigtning af bibelske figurer til at udspille forskellige temaer. Snarere end at undersøge, hvorvidt Kierkegaards tanker er akademisk korrekt adopteret af den eksistentielle og humanistiske psykologi og terapi, er det tilsvarende mere idéhistorisk vedkommende at forfølge Kierkegaards betydning gennem spørgsmålet: Hvordan og i hvilken form realiseres Kierkegaard som figur i forbindelse med fremstillingen af den eksistentielle og humanistiske tilgang, og 
hvilke temaer bruges figuren Kierkegaard til at bringe i spil? Artiklen vil derfor se på, hvordan figuren Kierkegaard er blevet bragt metodologisk $i$ anvendelse af fire af hovedskolerne inden for den eksistentielle og humanistiske tilgang fra 1930 og frem til i dag.

\section{Tilstedeværensanalyse (Daseinsanalyse)}

Den eksistentielle tilgang til psyfagene bliver etableret i Schweiz i 1930erne med afsæt i den skoledannelse, som kaldes Tilstedeværensanalyse (Daseinsanalyse). Historisk set er denne etablering en særegen udløber af en mere omfattende humanvidenskabelig modreaktion på den stærke naturvidenskabelige og teknologiske orientering af både psykologien, psykoterapien og psykiatrien, der præger de tysktalende lande $\mathrm{i}$ begyndelsen af det 20. århundrede. Den brede modreaktion opstår i 1920erne og tæller blandt andet den schweiziske psykiater og psykoanalytiker Ludwig Binswanger. I 1907 bliver Binswanger assistent for Eugen Bleuler og Carl Gustav Jung. Fra det tidspunkt forfølger han en interesse for Freuds perspektiver. Binswanger knytter også et livslangt venskab med Freud. Binswangers næsten ubetingede tilslutning til psykoanalysen varer dog kun indtil midten af 1920 erne. Her begynder han gradvist at forlade psykoanalysen og slutter sig til den såkaldte antropologiske reformbevægelse. Binswangers forste anstrengelser $\mathrm{i}$ den retning består i udgivelsen af værket Einführung ind die Probleme der allgemeinen Psychologie fra 1922. Værket rummer hans bestræbelse på at fremstille en ny psykologisk personvidenskab. Ifølge Binswanger må en psykologisk videnskab om mennesket som person forankres i udviklingen af en almenpsykologi, der har et langt mere helhedsorienteret syn på den intentionelle kerne i menneskets psykologiske subjektivitet end psykoanalysen. Derfor må den nye personvidenskab trække på et fænomenologisk perspektiv (Binswanger 1922: 103). Efterhånden knytter Binswanger sine bestræbelser til en ambition om at etablere et nyt videnskabeligt grundlag for den kliniske psykiatri og psykopatologi. Det nye grundlag skal muliggøre en fænomenologisk beskrivelse af psykopatologiske symptomer, som har et ikke-reduktionistisk greb om det specifikt menneskelige i den menneskelige eksistens.

I første omgang optræder Kierkegaard i Binswangers værk fra 1922 som en foregangsfigur, hvis psykologiske indsigter ifølge 
Binswanger glimrer ved at indgå i en slags personetik eller etik for individet. Binswanger mener, at Kierkegaards etiske tilgang til den individuelle person er tæet på det virkelige liv. Det skyldes, at tilgangen er baseret på idéen om, at individet kun kan blive bevidst om sig selv ved sig selv (Binswanger 1922: 324). Binswanger benytter således figuren Kierkegaard til at understøtte sin nye psykologiske videnskabs antropologiske orientering mod mennesket som person. I en artikel fra 1926 indplacerer han dog samtidig Kierkegaard i en mere omfattende spirituelt orienteret humanistisk tradition sammen med Augustin, William Shakespeare, Friedrich Nietzsche og Michel de Montaigne. Grunden til at Binswanger nu placerer Kierkegaard i dét selskab er, at han vil fremhæve Kierkegaard som en blandt flere litterære forfattere. En række forfattere, der nok kan tjene som inspiration for Binswangers reformbestræbelser i kraft af deres afgørende fokus på mennesket som person, men som alligevel er utilstrækkelige. Dette skyldes, at ingen af forfatterne gør brug af en videnskabelig metode (Binswanger 1994: III: 3). Derfor forsøger Binswanger i første omgang at inddrage indsigter fra Edmund Husserl og Franz Brentano. Alligevel når han gradvist frem til, at hverken Husserl eller Brentano giver ham et tilfredsstillende helhedsorienteret begreb om mennesket.

I kølvandet på Heideggers udgivelse af Varen og tid i 1927 opdager Binswanger, at han netop i dette værk bliver givet det nødvendige helhedsorienterede begreb om mennesket som Tilstedeværen (Dasein) (Heidegger 2007). Ifølge Heideggers opfattelse er mennesket som Tilstedeværen karakteriseret ved en grundlæggende Væren-i-verden. Denne idé om at mennesket altid allerede er til i en betydningsbærende livsverden, får stor betydning for Binswanger. Fra 1930 begynder han at implementere begrebet om Tilstedeværen $\mathrm{i}$ sit arbejde med at udvikle en konstruktiv bestemmelse af psykiatriens genstand. Det skal være en bestemmelse, der kan overvinde de problemer, som Binswanger forbandt med neuropsykiatrien og psykoanalysen. Nemlig ved at bestemmelsen ikke er funderet i reduktionistiske abstraktioner som 'hjernen' eller 'drifterne'. Binswanger vil have, at alle de psykiske manifestationer og fænomener hos den konkrete patient forstås som betydningsfulde aspekter af hele menneskets eksistens som Væren-i-verden. Det er netop derfor, psykopatologien må 
begrundes $\mathrm{i}$ en filosofisk konception af mennesket og ikke bare i den empiriske psykologi.

Heidegger kalder sit eksistensfænomenologiske projekt for Tilstedeværensanalytik (Daseinsanalytik). Hans sigte er at analysere de fundamentale ontologiske strukturer i menneskets eksistens for at kunne opnå en privilegeret tilgang til undersøgelsen af meningen med Væren som sådan. For Heidegger er der i den forbindelse tale om et eksistensorienteret forsøg på at modificere Husserls fænomenologi. Her trækker Heidegger på Kierkegaards idé om, at mennesket ikke har en fikseret essens, men først og fremmest eksisterer og derudfra må vælge sin skæbne. Binswanger er imidlertid ikke interesseret $i$ bare at overtage og anvende Heideggers ontologiske analyse af mennesket. Det er nemlig vanskeligt for ham at bruge et rent spekulativt projekt som udgangspunkt for hans kliniske klientarbejde. Binswanger er først og fremmest interesseret $i$ at få skabt en direkte adgang til menneskets konkrete eksistens i den kliniske praksis. Fra og med et foredrag i 1945 begynder Binswanger i den forbindelse at kalde sit forehavende Tilstedeværensanalyse (Binswanger 1994: III: 231-257). Hermed markerer han, at der er tale om en særegen udløber af psykoanalysen, der bygger på en klinisk psykiatrisk anvendeliggørelse af Heideggers filosofiske Tilstedeværensanalytik, og som derfor har den menneskelige Tilstedeværen og ikke psyken som genstand. Samtidig markerer Binswanger, at hans projekt lige netop ikke er filosofisk fundamentalontologi, men videnskabelig antropologi. En såkaldt ontisk fænomenologi. Binswanger er altså kritisk over for visse aspekter i Heideggers fundamentalontologi, og han bliver heller aldrig egentlig heideggerianer. Med sine egne tilbageskuende ord baserer han delvist sit projekt på en produktiv misforståelse af Heidegger (Binswanger 1994: II: 4). På tilsvarende vis kommer Kierkegaard nu til at optræde som en anvendt metodologisk figur i Binswangers værk. En figuration af Kierkegaard, der samtidig er andet og mere end blot formidlet gennem Heideggers eksistensfænomenologi.

Kierkegaard får en central betydning for Binswanger i forbindelse med den eksistensfænomenologiske drejning af hans projekt. Den drejning finder sted fra og med artiklen "Traum und Existenz" fra 1930. Kierkegaard får nu en betydning som figur på to forskellige måder. 
For det første $\mathrm{i}$ forbindelse med en tematisering af forholdet mellem det almene og det konkrete. Binswanger indleder sigende sin artiklen fra 1930 med et citat fra Kierkegaards Afsluttende uvidenskabelig Efterskrift fra 1846 om, "at man holder fast ved hvad det er at være Menneske" (Binswanger 1994: III: 95; SKS 7: 182). Binswangers grundlæggende ønske er at kombinere det antropologiske og det ontologiske niveau, så det kan fungere som afsæt for en direkte tilgang til den konkrete eksistens i det kliniske møde. Men han må også erkende, at Heideggers fundamentalontologiske Tilstedeværensanalytik netop ikke er tilstrækkelig til det formål. Binswanger vil være i stand til at kunne forstå sammenhængen mellem den konkrete patients helt individuelle psykopatologiske udtryk og de almene former i menneskets væren (Binswanger 1994: I: 132). Det kræver, at han tager udgangspunkt i en filosofisk bestemmelse af mennesket, der forbinder det partikulære og det almene niveau på en måde, som Heideggers Tilstedeværensanalytik ikke formår. Som løsning trækker Binswanger på Kierkegaard, der netop havde kritiseret den tyske filosof Georg Wilhelm Friedrich Hegels spekulative idealistiske system for ikke at give plads til hin enkelte og den subjektive sandhed forstået som den "objektive uvished, fastholdt i den meest lidenskabelige Inderligheds Tilegnelse" (SKS 7: 186). Binswanger kan altså bringe Kierkegaard i spil som teoretisk figur, fordi han har sans for forståelsen af relationen mellem det partikulære og det almene i den konkrete tilværelse (Binswanger 1994: III: 166). Binswanger kan anvende dette spænd til at forene individualiteten i den kliniske case med psykiatrien som eksistensfænomenologisk videnskab. Han omsætter derfor spændet til et gennemgående klinisk princip om at afklare den eksistentielt-antropologiske struktur i klientens erfaringer. Både i drømmeskriftet fra 1930 og i værket Über Idéenflucht fra 1933 bliver Kierkegaard endvidere bragt i spil som teoretisk figur, fordi Binswanger uddybende ønsker at tematisere det eksistentielle princip bag de psykiske manifestationer i klienternes erfaringer (Binswanger 1994: III: 132). Her benyttes Kierkegaard således til at vise, at klientens erfaringer er manifestationer af henholdsvis selvets fortabelse og virkeliggørelse i verden.

For det andet ser vi Kierkegaardfigurens rolle i forbindelse med Binswangers problematisering af psykopatologien. Her starter vi ved den måde, hvorpå Kierkegaard i Begrebet Angest fra 1844 havde 
formuleret sig således: "Uskyldigheden er Uvidenhed. I Uskyldigheden er Mennesket ikke bestemmet som Aand, men sjelelig bestemmet i umiddelbar Eenhed med sin Naturlighed. Aanden er drømmende i Mennesket” (SKS 4: 347).

I drømmeskriftet fra 1930 havde Binswanger tilsvarende benyttet sig af Kierkegaard til at sammenligne drømmen med en uvirkeliggjort tilstand i mennesket, der kunne standses af en lidenskabelig åndelig opvågnen $\mathrm{i}$ inderlighed (Binswanger 1994: III: 116). I 1933 anvender Binswanger figuren Kierkegaard i selskab med Heidegger og Karl Jaspers til at beskrive, hvordan selvets autentiske virkeliggørelse kan tematiseres som en opvågnen fra hverdagslivets overfladiske uselvstændighed og uansvarlighed (Binswanger 1994: I: 132). Omvendt skal de psykopatologiske fænomener forstås som manifestationer af en fortabelse af selvet i den verden, der udgør menneskets livshistoriske rum.

I artiklen "Die Bedeutung der Daseinsanalytik Martin Heideggers für das Selbstverständnis der Psychiatrie" fra 1949 formulerer Binswanger denne indsigt endnu mere præcist. Det gør han med direkte reference til Kierkegaard. Binswanger beskriver nemlig, hvordan oprindelsen til de psykiske lidelser er et forfald af de eksistentielle muligheder: de muligheder, der konstituerer den menneskelige eksistens, og dermed bliver mennesket fanget i sin ufrihed (Binswanger 1949: 70). Figuren Kierkegaard har altså en væsentlig betydning for Binswangers forsøg på at reformere den konventionelle psykopatologi. Den betydning bliver endnu mere eksplicit i casestudiet "Sagen Ilse" fra 1945. Her anfører Binswanger direkte, at grundlaget for den antropologisk-eksistentielle problematisering af psykopatologi er Kierkegaards filosofiske begreb om sygdommen til døden fra værket af samme navn fra 1849. Binswanger er mere præcist interesseret $i$ Kierkegaards tematisering af fortvivlelsen ikke at ville være sig selv og fortvivlelsen at ville være sig selv (Binswanger 2004: 236; SKS 11: 129). Og det er netop dette forhold, at mennesket ikke har et inderligt forhold til det uendelige og derfor bliver lukket inde i sig selv, som udkrystalliserer sig i de forskellige former for psykopatologi. Ifølge Binswanger er skizofreni blot er en særligt intensiv variant af den fortvivlelse, som handler om, at mennesket lukker sig inde i sig selv.

For Binswanger kommer indsigterne fra Heidegger til at fungere 
som en programmatisk løftestang for hans ambition om at levere et filosofisk fundament for den kliniske praksis. Derimod trækker Binswanger meget mere specifikt på figuren Kierkegaard. Det gør han altså på to måder for at kunne give et mere håndgribeligt greb om det konkrete og kliniske aspekt i den psykiatriske praksis. Hos Binswanger finder vi således først figuren Kierkegaard i skikkelse af en af humanismens psykologiske tænkere. Senere finder vi Kierkegaard som en figur, der inkarnerer en sans for sammenhængen mellem det almene og det konkrete. I den forbindelse bliver Kierkegaard ikke mindst en figur, som bruges til at demonstrere den almene struktur i de konkrete psykopatologiske tilfælde. Altså at det enkelte menneskes psykiske forstyrrelse indeholder et almenmenneskeligt element.

Efter anden verdenskrig grundlægger den schweiziske psykiater Medard Boss en ny skole inden for Tilstedeværensanalysen, som frem til 2010erne blandt andet bliver videreført af Gion Condrau og Alice Holzhey-Kunz. Til forskel fra Binswanger er den nye skoles primære anliggende at udvikle en mere direkte og ukritisk anvendeliggørelse af Heideggers lære på det psyfaglige felt. Heidegger får altså en langt mere fremtrædende rolle $\mathrm{i}$ det nye forehavende, end han havde hos Binswanger. Figuren Kierkegaard får derimod ikke nogen egentlig rolle og fordufter nærmest som refereret teoretisk inspirationskilde. Ganske vist optræder Kierkegaard i den omtalte sammenhæng, men det er primært som en figur, der er formidlet igennem Heideggers projekt.

\section{Den humanistiske psykologi og psykoterapi}

Mens Tilstedeværensanalysen opstår i Schweiz i 1930erne, varer det ikke længe, førend der også opstår en psykologisk retning i USA, som ligeledes arbejder med eksistentielt orienterede emner og er inspireret af eksistensfilosofien og fænomenologien. Denne humanistiske psykologi og psykoterapi bliver i det væsentlige lanceret som et modsvar til både behaviorismen og psykoanalysen. Derfor bliver den også fremstillet som den tredje kraft i psykologien.

Initiativtageren til den udvikling er den amerikanske psykolog og tidligere teologistuderende Carl Rogers. Fra 1940erne lancerer Rogers en ny teoretisk tilgang til psykologien ud fra den opfattelse, 
at hverken psykoanalysen eller behaviorismen evner at forstå det enkelte menneske som en unik person. Til det formål lader Rogers sig bl.a. inspirere af eksistensfilosofferne Martin Buber og Paul Tillich. Som det fremgår af Rogers' sene værk On becoming a person fra 1961, har Kierkegaard imidlertid også en helt central betydning for hans projekt (Rogers 2004: 199). I den forbindelse påpeger Rogers dog også, at der på nogle afgørende punkter er en manglende samklang mellem ham selv og Kierkegaard. Den uoverensstemmelse med Kierkegaard skal til dels ses i lyset af, at Rogers afviser berettigelsen af religion (Kirschenbaum 1990: 72).

I midten af det 20. århundrede er især behaviorismen fremherskende i USA, og ifølge Rogers reducerer den tilgang personen til et objekt ved at begrænse forståelsen af menneskets tanke-, følelsesog handlingsliv. Rogers mener således, at behaviorismen indskrænker forståelsen af mennesket til at bestå i et objektivt studie af menneskets rent iagttagelige adfærd, der ifølge behaviorismen kan generaliseres til almene lovmæssigheder. I den anledning trækker Rogers i On becoming a person på Kierkegaard som en visionær figur, der kan bruges som afsæt for en kritik af behaviorismen. Ifølge Rogers var Kierkegaard allerede i den tidlige modernitet foregangsfigur for et oprør mod de dehumaniserende og objektiverende tendenser i den sociale og kulturelle orden (Rogers 2004: 214). Hos Rogers får Kierkegaard altså status som en modernitetskritisk profet, der kan bidrage til at legitimere Rogers’ oprør mod den naturvidenskabelige og teknologiske psykologi.

Som et alternativ vil Rogers i stedet lade sin nye humanistiske tilgang til psykologien gå fænomenologisk til værks og forsøge at begribe, hvordan det enkelte menneske oplever verden. I forhold til Binswanger og hans eksistensfænomenologiske fokus på menneskets Væren-i-verden er Rogers endvidere stærkt præget af den amerikanske kultur. Rogers har derfor ikke bare et langt mere positivt og optimistisk, men også langt mere individualistisk syn på mennesket. Hans psykologiske tilgang fremhæver i den sammenhæng udviklingen af menneskets individualitet og dets iboende muligheder. I modsætning til de fleste andre samtidige psykologiske tilgange tager Rogers udgangspunkt i det sunde individ. Afsættet for hans tilgang til psykologien er således, at menneskets motivation kan forklares ud fra en trang til at opnå personlig vækst gennem 
selvaktualisering (Rogers 2003: 489). Ifølge Rogers vil ethvert menneske under de rette omstændigheder derfor udvikle et rigt selv, der er præget af et harmonisk følelses-, tanke- og handlingsliv. I On becoming a person inddrager Rogers et citat fra Kierkegaards Sygdommen til Døden til at forklare dette livsmål som et spørgsmål om at blive det selv, som man i sandhed er (Rogers 2004: 166, 181; SKS 11: 130). Samtidig udlægger han selvaktualiseringen som en personlig tilblivelsesproces. I den forbindelse inddrages et citat fra Kierkegaards Afsluttende widenskabelig Efterskrift til at beskrive tilblivelsesprocessen som en vedvarende fødsel af muligheder snarere end som en bevægelse mod et fikseret mål (Rogers 2004: 172; SKS 7: 114).

I den sammenhæng beskriver Rogers endvidere den personlige tilblivelsesproces som et spørgsmål om, at individet må fralægge sig de masker og facader, vi som mennesker iklæder os for at leve op til forventningerne om, hvordan vi tror, vi skal være (Rogers 2004: 110). Med andre ord handler den personlige tilblivelse om at lade maskerne og facaderne falde, så vi kan blive autentiske væsner. Til at understøtte det formål inddrager Rogers en sentens fra Sygdommen til Døden. Her kan han nemlig bruge figuren Kierkegaard til at beskrive, hvordan det enkelte menneskes dybeste eksistentielle fortvivlelse er et udtryk for et valg om at være en anden end det selv er (SKS 11: 136). Ifølge Rogers glimrer Kierkegaard netop ved, at han $\mathrm{i}$ en meget omfattende forstand er i stand til at beskrive fortvivlelsen ikke at ville være sig selv. Mens Binswanger også havde inddraget figuren Kierkegaard til at kunne tematisere fortvivlelsen at ville være sig selv, ser Rogers imidlertid kun selvaktualiseringen som en positiv proces. At ville være sig selv kan derfor ikke være forbundet med fortvivlelse, det kan kun valget ikke at ville være sig selv. Ifølge Rogers er psykiske lidelser så udtryk for en form for inautenticitet, der bliver udløst af, at mennesket bliver hindret i dets tendens til selvaktualisering. Vi bliver altså psykisk forstyrrede, hvis vi bliver forhindret $i$ at blive os selv. Til gengæld rummer det enkelte menneske også ressourcerne til at håndtere dets egne psykiske problemer, såfremt de rette vækstfremmende betingelser altså er til stede (Kirschenbaum 1990: 27). Hos Rogers bliver figuren Kierkegaard med andre ord også tematiseret som en foregangsmand for personlig selvaktualisering gennem menneskelige valg. Næsten ligesom hos Binswanger bruger Rogers i samme ombæring Kier- 
kegaard til at skematisere den dynamiske forskel mellem personlig vækst og lidelse.

Rogers knytter allerede fra starten sin lancering af den nye humanistiske tilgang til psykologien til udviklingen af et grundlag for en ny tilgang til psykoterapien. Rogers' nye tilgang til psykoterapien bliver hurtigt meget udbredt i USA. Hans særlige tilgang til psykoterapien kan bedst beskrives som en humanistisk modificering af psykoanalysen. Rogers formulerer grundlaget for den nye form for psykoterapi i Counselling and Psychotherapy fra 1942 og Client-Centered Therapy fra 1951 (Rogers 1942; 2003). I første omgang giver Rogers sin psykoterapeutiske tilgang navnet "klient-orienteret terapi". Senere omdøber han tilgangen til "person-orienteret terapi" for at fremhæve, hvordan denne psykoterapeutiske tilgang er baseret på en grundlæggende anerkendelse af det enkelte menneske som unik person. Terapiens mål er at skabe de vækstfremmende betingelser for, at den selvaktualiserende tendens i det enkelte individ som person kan udfoldes.

Ifølge Rogers er det altså netop denne selvaktualisering, som antageligvis bliver hindret og blokeret. Den person-orienterede terapi skal med andre ord hjælpe det menneske, som bliver forhindret i at blive sig selv. Rogers gør rede for, hvordan terapeuten i den forbindelse må benytte en såkaldt non-direktiv metode. Endvidere må terapeuten benytte et fænomenologisk udgangspunkt til at lade klientens oplevelser få plads gennem brug af afspejlende aktiv lytning, empati og accept. Her inddrages Kierkegaards sokratiske læringsmodel til at skildre terapien som en maieutisk sandhedspraksis. Rogers bruger således en implicit reference til Kierkegaards værk Philosophiske Smuler fra 1844 til at beskrive, hvordan terapeuten ikke direkte kan lære klienten at blive autentisk og derfor heller ikke kan dirigere terapien. Terapeuten kan dermed ikke hjælpe klienten ved at undervise klienten igennem det, Rogers kalder en ordinær læringsproces. I stedet må terapeuten indirekte facilitere en vækkelse af klientens egen accept af sin subjektive sandhed om sig selv, som Rogers benævner en "genuin læringsproces" (Rogers 1994: 308; 2004: 204; SKS 4: 236).

Hos Rogers finder vi altså en noget anderledes anvendelsesorienteret figuration af Kierkegaard end hos Binswanger. Nemlig en figuration af Kierkegaard, der som en modernitetskritisk profet 
polemiserer imod systemets diktatur over individet. En profet, der som modsvar til systemets diktatur advokerer for, hvordan vi må orientere os mod at fremme individuel selvaktualisering gennem en uforvansket og indirekte læringsproces. I udviklingen af den humanistiske psykologi og psykoterapi bliver Rogers fra 1950erne især bistået af Abraham Maslow, som bliver et andet hovednavn inden for tilgangen. Maslows projekt inddrager imidlertid ikke eksplicit Kierkegaard som metodologisk figur, men Kierkegaard er til stede $i$ ånden som en implicit del af overleveringen fra Rogers (jf. Maslow 2011). I de senere års aktuelle udvikling af den humanistiske tilgang, optræder Kierkegaard da heller ikke som en eksplicit inspirationskilde. I stedet er inspirationen fra Kierkegaard blevet en implicit og tavs del af tilgangens teoretiske grundlag.

\section{Den humanistisk-eksistentielle tilgang}

Først i 1958 finder Tilstedeværensanalysen fra det europæiske kontinent officielt vej til USA. Det sker med udgivelsen af antologien Existence, som både rummer helt nye bidrag fra de amerikanske redaktører samt en række oversættelser af europæiske tekster af bl.a. Binswanger (May 2004). Året efter afholder The American Psychological Association et stort symposium om emnet 'eksistentiel psykologi', og foredragene herfra bliver udgivet i antologien Eksistentiel psykologi (May 1960).

Det er den amerikanske psykolog Rollo May, der er primus motor for den amerikanske import og ombearbejdning af den eksistentielle tilgang. Den særegne amerikanske aftapning af den eksistentielle psykologi og terapi bliver hurtigt meget snævert knyttet til udviklingen af den humanistiske psykologi og person-orienterede psykoterapi (jf. May 1986). May er fælles med Rogers om at have et kritisk udgangspunkt, der vedrører en bekymring over den dominerende rolle, som videnskabelige og eksperimentelle tilgange har inden for amerikansk psykologi og terapi i tiden omkring anden verdenskrig. Mange har ligefrem opfattet den eksistentiel-humanistiske psykologi som en del af den humanistiske psykologi og psykoterapi, og allerede hos Rogers og May ser vi da også en fælles betoning af individets subjektive og personlige erfaring som modsætning til den naturvidenskabeligt orienterede psykologis præference 
for det objektive.

I 1930erne studerer May ikke alene under Alfred Adler i Wien, der er kendt for sin lancering af individualpsykologien med dens opfattelse af mennesket som et individuelt hele. Han studerer også teologi under Paul Tillich, der introducerer May til den eksistentielle tænkning. Da May i slutningen af årtiet skifter fra teologien til psykologien, medbringer han disse to dimensioner til feltet. Den import kommer til at manifestere sig $\mathrm{i}$ en fokusering på det hele eksisterende individ, der ifølge May må begribes, som det hele tiden bliver til og forandrer sig (May 1960: 11).

Mens Kierkegaard er fraværende i den første del af Mays forfatterskab, får han en helt afgørende metodologisk rolle i værket The Meaning of Anxiety fra 1950. May skriver delvist værket under et ophold på et tuberkulosesanatorium, og det er der i sygesengen, at han opdager Kierkegaard som en figur, der netop har sans for angsten som et konkret fænomen og oven i købet selv kender til den (May 1983: 14-15). Det er baggrunden for, at May i værket $i$ markant grad trækker på indsigter fra Begrebet Angest og Sygdommen til Døden. Det længste kapitel i The Meaning of Anxiety er ligefrem helt og holdent helliget Kierkegaard. I værket fremtræder Kierkegaard først og fremmest som en figur, May bruger til at understøtte et teoretisk fokus på angsten med henblik på at gøre angsten til omdrejningspunkt for den psykologiske forståelse af mennesket. Ifølge May har både psykoanalysen og den eksistentielle tradition fortalt os, at angsten er blevet et centralt problem i den moderne vestlige civilisation (May 1996a: 34). May mener endvidere, at dét problem nærmere består $i$, at det moderne menneske har vanskeligt ved at konfrontere sin angst og derfor får psykiske problemer. En vanskelighed, der hovedsageligt skyldes, at det moderne menneske er blevet fremmedgjort for sin egen selvbevidsthed på grund af en kulturel tendens til at undertrykke irrationelle erfaringer (May 1996a: 21). I den forbindelse er Kierkegaard vigtig for May, fordi Kierkegaard ikke alene formulerer en væsentlig indsigt $\mathrm{i}$ angstens karakter som en frygt for intetheden, men også artikulerer en betydningsfyld sans for angstens læringspotentiale (May 1996a: 15). Kierkegaard har nemlig forstålse for, at angsten ikke alene kan føre til fortvivlelse, hvis individet flygter fra den. May refererer direkte til Begrebet Angest, idet han påpeger, hvordan Kierkegaard således har 
indset, at angsten også er frihedens mulighed, og at selvets positive udvikling afhænger af individets evne til at konfrontere angsten og overkomme sine angstprovokerende livserfaringer (SKS 4: 348; May 1996a: 39, 247, 393).

I modsætning til Binswanger finder vi hos May altså det samme individualistiske udgangspunkt som hos Rogers. Men Rogers benytter figuren Kierkegaard til at understøtte en meget positiv fremstilling af eksistensens sundhed og udviklingspotentiale, der bliver et kendetegn for den humanistiske psykologi og terapi. Her trækker May omvendt på figuren Kierkegaard for at understøtte en fremstilling af angsten som eksistensens grundstruktur og den menneskelige tilværelses begrænsninger, og dermed indarbejder han et mere tragisk syn på mennesket, som bliver et kendetegn for den eksistentiel-humanistiske psykologi og udgør dens primære forskel fra den humanistiske psykologi og terapi. De fælles grundantagelser og arven fra den amerikanske kulturtradition fornægter sig dog ikke. Hvor Rogers i den sammenhæng skildrer den eksistentielle læringsproces som forbundet med vækst gennem valg, følger May i Man's Search for Himself fra 1953 næsten tilsvarende op på sit værk fra 1950 ved at benytte figuren Kierkegaard til at beskrive, hvordan selvets positive udvikling forudsætter det enkelte menneskets bekræftelse af ansvaret for sig selv og sin egen eksistens (May 1993: 168). Endvidere anvender han i den forbindelse frasen "Hjertets reenhed er at ville Eet" fra Kierkegaards En Leiligheds-Tale fra 1847 for at fremhæve, at frihedens mulighed ikke handler om tilpasning til ydre forhold, men er en inderlighedens etik. Mennesket bringer hermed sin subjektivitet i overensstemmelse med sandheden gennem en indre tilegnelse. May oversætter her inderlighedsprincippet fra en religiøs til en verdslig ramme (May 1993: 221; SKS 8: 138).

I bogen Psychology and the Human Dilemma fra 1967 bringer May igen figuren Kierkegaard i spil som en frihedens tænker, men han uddyber nu, at Kierkegaard samtidig er en paradoksets tænker (May 1996b: 20). Det giver May mulighed for at tematisere, hvordan menneskets frihed er forbundet med en forpligtelse til at vælge $i$ konfrontationen med angsten. For Kierkegaard indebærer friheden ifølge May, at individet efterhånden udvikler en selvbevidsthed om sine egne muligheder, og hermed former der sig også et psykologisk grundlag for ansvar, skyld og indre konflikt (May 1996b: 67-9). Den 
neurotiske angst opstår i den forbindelse som et resultat af en eksistentiel tillukning, hvor individet blokerer for sin selvbevidsthed og frihedserfaring på grund af en frygt for friheden og dens følger. I den neurotiske angst er individet derfor både udelukket fra sig selv og andre, og i konfrontationen med angsten er vi således fundamentalt set stillet over for enten aktivt at løbe en risiko eller passivt at gå til grunde.

I forlængelse af May er den eksistentiel-humanistiske psykologi fortrinsvis blevet videreudviklet af James Bugenthal, Irvin D. Yalom og Kirk Schneider fra 1960erne og frem til 2010erne. Her bliver inspirationen fra Kierkegaard mindre og er især filtreret gennem aftapningen fra May. Hos Bugenthal, Yalom og Schneider genfinder vi derfor forst og fremmest figuren Kierkegaard gennem skildringen af ham som en tænker, der kan understøtte den eksistentiel-humanistiske psykologis individualistiske orientering i kraft af sin sans for angstens eksistentielle dybde og for forbindelsen mellem angst og frihed som en forudsætning for individets udvikling eller som kimen til det neurotiske liv.

\section{Den britiske eksistensanalyse}

I 1960erne opstår der en selvstændig eksistentiel tilgang til psykiatrien i Storbritannien, som ikke blot er bredt inspireret af den kontinentale eksistensfilosofi og eksistensfænomenologi, men også af Jaspers' og Eugené Minkowskis fænomenologiske psykiatri og i mindre omfang af Tilstedeværensanalysen. Hovedaktøren og ophavsmanden er den skotske psykiater Ronald D. Laing, der desuden trækker på inspiration fra den samtidige objektrelationsteori, interpersonelle psykiatri og systemiske familieterapi. Laing forklarer selv, at han ikke er inspireret af én bestemt eksistentiel position (Laing 2010). Han trækker i en mere bred forstand på eksistentielt tankegods $i$ sin fortløbende formulering af en tilgang til psykiatrien, som ikke alene adskiller sig markant fra de amerikanske skolers individualistiske orientering ved at betone menneskets relationalitet. I den forbindelse går Laings tilgang også videre end de schweiziske tilstedeværensanalytikere ved at påpege, at mennesket ikke kan forstås uafhængigt af sin sociale, kulturelle og politiske sammenhæng. 
Figuren Kierkegaard optræder kun sporadisk hos Laing, men får til gengæld en mere fremtrædende rolle i den britiske eksistensanalyse, der opstår i 1980erne som en selvstændig udløber af bl.a. Laings projekt. Det er den hollandsk-britiske psykolog og filosof Emmy van Deurzen, der er primus motor for etableringen af denne skoledannelse, som i lighed med Laing afviser de amerikanske tilganges individualisme og subjektivisme og forfægter eksistensens fundamentale relationalitet og indfældethed i verden. Deurzen indtager desuden sin helt egen originale position inden for den britiske eksistensanalyse, der eksplicit trækker på aspekter fra hele den eksistentielle og fænomenologiske tradition inden for filosofien og psyfagene. I denne positionering får figuren Kierkegaard en væsentlig metodologisk betydning fra og med Eksistentiel samtale og terapi fra 1987 og tildeles desuden et selvstændigt afsnit i Eksistentielle dimensioner $i$ psykoterapi fra 1997, hvor Deurzen leverer et forsøg på en konstruktiv sammenfatning af Kierkegaards tanker og deres relevans for eksistensanalysen.

I forbindelse med formuleringen af udgangspunktet for sin position trækker Deurzen direkte på figuren Kierkegaard og inddrager delvist et citat fra Afsluttende wvidenskabelig Efterskrift som underbygning (SKS 7: 171; Deurzen 1999: 22). Idéen er, at eksistensens kerne består deri, at livet er en endeløs kamp, hvor mennesket hele tiden konfronteres med eksistentielle udfordringer. I lighed med Mays bestræbelser inddrager Deurzen også Kierkegaard for uddybende at tematisere, hvordan mennesket i konfrontationen med disse udfordringer uundgå ligt vil opleve angst (Deurzen 1999: 25; 2006: 68; 2011: 22). Samtidig fremhæver hun, at Kierkegaard lige netop havde sans for, at vi ikke skal forsøge at fjerne livets udfordringer men derimod lære at se angsten i øjnene på den rigtige måde for at gennemleve og overvinde fortvivlelsen. I Psychotherapy and the Quest for Happiness fra 2009 påpeges i den forbindelse, at Kierkegaard forbandt fortvivlelsen med en forsagelse af Gud, men at vi som senmoderne mennesker i et vist omfang lever i en tid, hvor livets kamptag med fortvivlelsen må udkæmpes efter andre ledestjerner end Gud (Deurzen 2009: 28). Med en reference til Sygdommen til Døden pointerer Deurzen, at fortvivlelsen både kan antage en svag og en undvigende form, men også at den kan være afsættet for at lære at leve livet. 
Deurzen påpeger, at Kierkegaards andet centrale bidrag til eksistensanalysen er understregningen af, hvor vigtigt det er for os at kunne leve med vores tilgrundliggende paradoks, som vi konfronteres med i erfaringen af angsten (Deurzen 2011: 22). Her bruges Kierkegaard til at beskrive, hvordan selvet er en konstant tilblivelsesproces i en paradoksal sammensætning af modsætninger, som vi må overvinde gennem en individuel indsats for at undgå fortvivlelsen (Deurzen 2005: 162; 2009: 22). Ifølge Deurzen er Kierkegaard kendetegnet ved en fokusering på menneskets individuelle selvforhold og dets forhold til Gud, som må suppleres i en forståelse af, hvordan mennesket både lever i relationer til sig selv, andre mennesker, omverden og den spirituelle verden, hvor det er til i spændingsfeltet mellem en række poler, som det må omfavne.

For det tredje finder vi Kierkegaard som autenticitetens tænker, hvilket skal underbygge en forestilling om, at mennesket skal følge sine egne styrende principper i kunsten at leve sit liv og hermed følge sin egen samvittighed i konfrontationen med livets udfordringer (Deurzen 2006: 86).

Siden 1990erne er Deurzen især blevet suppleret af Hans Cohn og Ernesto Spinelli inden for den britiske eksistensanalyse, og her finder vi en langt mindre udtalt inspiration fra Kierkegaard.

\section{Sammenfatning af Kierkegaards gennemslag}

Hos Kierkegaard indgår de psykologiske tanker som metodiske redskaber i de overordnede filosofiske og teologiske overvejelser. I den eksistentielle og humanistiske tilgang til psyfagene vendes disse bestræbelser i et vist omfang på hovedet. Nemlig idet Kierkegaards filosofisk-psykologiske tanker renses for det teologiske element og benyttes som metodiske redskaber i en række psykiatriske, psykoterapeutiske og psykologiske overvejelser.

De forskellige teoretikere fra Binswanger og frem til Deurzen benytter imidlertid også figuren Kierkegaard som element i en noget anderledes strategi, end den vi først og fremmest ser i Kierkegaards brug af forskellige figurer i den indirekte meddelelse. I de eksistentielle og humanistiske tilgange til psyfagene finder vi nemlig et langt mere formaliseret syn på eksistensen. Formålet med teorierne og tekstmaterialet er først og fremmest, at de skal indgå i for- 
mulering, udvikling og formidling af en klinisk praksis, snarere end at de skal bidrage til læserens personlige udvikling.

Samtidig er det et gennemgående træk i de forskellige eksistentielle og humanistiske tilgange til psyfagene, at de hverken er baseret på en konstitutiv fundering i Kierkegaards forfatterskab eller trækker på en sammenhængende forståelse af forfatterskabet. Kierkegaard er med andre ord hverken hovedinspirationskilde eller hovedgrundlag for nogle af tilgangene. I stedet inddrages figuren Kierkegaard blot som én blandt flere teoretiske impulser fra den eksistensfilosofiske og eksistensfænomenologiske tradition. I den forbindelse er de forskellige teoretikeres inspiration fra Kierkegaard gennemgående præget af en eklektisk ambition. Vi ser nemlig, at de omtalte teoretikere anvender nogle meget selektive og afgrænsede konstruktioner af figuren Kierkegaard, og det gør de for at underbygge deres egen teoretiske agenda. Derfor finder vi også nogle forholdsvist forskellige figurationer af Kierkegaard, der tilsvarende benyttes som metodisk input og underbygning i nogle forholdsvist forskellige sammenhænge.

Vi ser imidlertid også, at der er et vist fællestræk i den måde, som de forskellige teoretikere inddrager figuren Kierkegaard på: først og fremmest som redskab til at formulere og underbygge nogle helt nye eksistentielle og humanistiske hovedtilgange til psyfagene. Figuren Kierkegaard benyttes med andre ord som teoretisk armering i en række nyskabende bestræbelser på at artikulere nogle banebrydende overvejelser. For pionerernes efterfølgere bliver indsigterne fra Kierkegaard derefter i høj grad til en slags implicitte antagelser, og ingen af dem synes at drage videre brug af figuren Kierkegaard. Hermed ser vi også, at der er en markant dobbelthed i den måde, hvorpå figuren optræder i de eksistentielle og humanistiske tilgange. Nemlig dels som en radikal og slagkraftig rambukfigur, der både repræsenterer en dyb visdom og en revolutionær sans, og dels som en nærmest anonym og uanselig baglandsfigur, der gøres til en næsten overflødig og banal selvfølgelighed.

Kigger vi nærmere på, hvilken del af Kierkegaards forfatterskab, der bringes i anvendelse, ser vi, at det i realiteten drejer sig om et ret begrænset udvalg af Kierkegaards tekster. Det er især værkerne Sygdommen til Døden, Begrebet Angest og Afsluttende wvidenskabelig Efterskrift, der anvendes, omend et mindre udsnit af det øvrige 
forfatterskab også benyttes.

Den mest gennemgående figuration af Kierkegaard i de eksistentielle og humanistiske tilgange til psyfagene finder vi i forbindelse med påpegningen af, hvordan psykiske lidelser og forstyrrelser har et almenmenneskeligt grundlag. Det forhold forklarer i udgangspunktet, hvorfor det er lige netop de tre omtalte værker, som står øverst på hitlisten blandt de eksistentielle og humanistiske teoretikere. Det er nemlig først og fremmest heri, at Kierkegaard gør rede for, hvordan eksistensen stiller sig som et problem, der helt og holdet udgør et individuelt valg, samt at menneskets fortvivlelse må henføres til måden, hvorpå den eksisterende konfronteres med angsten og bliver stillet over for eksistensen som en opgave.

På tværs af de forskellige eksistentielle og humanistiske tilgange ser vi altså en nærtbeslægtet interesse for Kierkegaards tematisering af den eksistentielle angst og fortvivlelse. Det forklarer også, hvorfor Kierkegaard repræsenterer en rambukfigur inden for de forskellige tilgange. Kierkegaards radikalitet og slagkraftighed er nødvendig for de eksistentielle og humanistiske tilgange til psyfagene, der historisk set har repræsenteret reformbevægelser og moddiskurser i forhold til mere konventionelle tilgange. Kernen i de moderne kliniske psyfag har siden det 19. århundrede bestået $\mathrm{i}$ den moderne psykopatologi og delvist i de hertil knyttede diagnostiske kriterier og kategorier. Det historiske grundlag for etableringen og udviklingen af de eksistentielle og humanistiske tilgange til psyfagene har derimod netop bestået i gennemgående kritik af den moderne psykopatologi og diagnosticering. I et eksistentielt og humanistisk perspektiv skyldes kritikken, at den konventionelle teori og praksis med sin fundering i psykopatologien og den diagnosticerende metodik involverer en objektiverende og tingsliggørende forståelse og håndtering af menneskelige lidelser og af lidende mennesker. Dermed udelukker psykopatologiseringen og diagnosticeringen mennesket fra at forholde sig til sig selv og andre mennesker som hele og ufærdige eksistenser med en fundamental frihed $i$ åben mulighed for livet.

I den forbindelse bliver figuren Kierkegaard central og nødvendig for de eksistentielle og humanistiske bestræbelser på at reformere psyfagene. Kierkegaard formår bedre end nogen andre at tematisere det almene i den fortvivlelse, som følger af, at vi ikke 
påtager os eksistensen som en opgave i vores konfrontation med angsten. Modsat den moderne psykopatologiske og diagnostiske fornuft skelner Kierkegaard ikke klart mellem psykiske forstyrrelser og angst som en eksistentiel disposition, men tematiserer det almene grundlag for menneskets eksistentielle og åndelige lidelse. Derfor giver Kierkegaard også et afsæt for at begribe denne lidelse i en eksistentiel, åndelig og etisk forståelsesramme som et spørgsmål, der handler om det konkrete hele menneske og dets levede liv. Således repræsenterer Kierkegaard et adækvat alternativ til den objektivering og reducering af den menneskelige erfaring, som følger af at begribe lidelsen i en funktionalistisk og teknologisk forståelsesramme. En begribelse af lidelsen som psykopatologiske forstyrrelser af menneskets livsfunktioner, der følger universelle lovmæssigheder og kan identificeres gennem brug af specifikke diagnoser.

Kierkegaards indsigter bliver tilsyneladende banale, når forst den moderne psykopatologi og diagnosticering er slået ned. Idet idéerne om angst og fortvivlelse, individualitet og valg renses for den spirituelle dimension, forfalder de åbenbart nemt til selvfølgelige indforståetheder. Alligevel har Kierkegaards indgang til lidelsen måske større relevans i vores nære samtid, end den nogensinde tidligere har haft. Den psykopatologiske og diagnostiske fornuft har aldrig været så udbredt, som den er nu, og menneskets opgave med at påtage sig eksistensen har aldrig været filtret ind i så mange lag af sociale og kulturelle forhindringer, som den i vores samtid.

Samtidig har Kierkegaards tanker også usædvanligt svære vilkår inden for rammerne af de konventionelle psyfag, som er mere prægede af flad og instrumentel tænkning, end de var i begyndelsen af det 20. århundrede. I disse år gennemstrømmes psyfagene således af positive, kognitive, neurovidenskabelige, genetiske, psykofarmakologiske og systematiserende bestræbelser i et hidtil uset omfang. Samtidig synes den tiltagende orientering mod evidensbasering og instrumentalisering samt den aktuelle ekspansion af psykopatologien og diagnosticeringen at true med at endimensionalisere det psyfaglige felt og gøre den kliniske fornuft ensrettet. Derfor er der også et aktuelt behov for kritiske reformbestræbelser og moddiskurser inden for psyfagene, som de eksistentielle og humanistiske tilgange hidtil har været blandt de fremmeste repræsentanter for. I den forstand er Kierkegaards indsigter ikke altmodisch, men deri- 
mod frugtbare for den stadige reformering af psyfagene, og det gælder ikke mindre i en tid, hvor den teknologiske og antropologiske fornuft synes at blive udfordret via en ny genkomst af spirituelle tanker.

Som Heidegger proklamerede i 1976, vil kun tilsynekomsten af en ny gud kunne redde mennesket fra dets egen bestræbelse på blive verdens centrum og gøre alt $\mathrm{i}$ og omkring sig selv disponibelt som ressource for sin egen beregneliggørelse og kontrol (Heidegger 1976). Hermed har Kierkegaard ikke alene stadig relevans for de eksistentielle og humanistiske bestræbelser på at reformere psyfagene med henvisning til en eksistentiel forståelse af den menneskelige lidelse. Kierkegaard er også særligt relevant for dé nye eksistentielle og humanistiske tilgange til psykiatrien, psykologien og psykoterapien, som forsøger at integrere en spirituel dimension i forståelsen af eksistensen. Den spirituelle dimension er ellers blevet ihærdigt udelukket i traditionen fra Binswanger, Rogers og May, som har forsøgt at undvige det religiøse. Det skyldes i høj grad, at den hidtidige eksistentielle og humanistiske tradition har været historisk forankret i den antropologiske fornuft og oplysningsprojektet. Men i kølvandet på den aktuelle spirituelle vending bliver det stadig mere relevant at inddrage et åndeligt aspekt i psyfagene, som ikke nødvendigvis begrunder sig i faste religioner og dogmer.

\section{Litteratur}

Binswanger, Ludwig (1922): Einfübrung in die Probleme der allgemeinen Psychologie, Berlin: Springer.

Binswanger, Ludwig (1949): "Die Bedeutung der Daseinsanalytik Martin Heideggers für das Selbstverständnis der Psychiatrie" i C. Astrada (red.), Martin Heideggers Einfuss auf die Wissenschaften, Bern: Francke.

Binswanger, Ludwig (1994): Ausgewäälte Werke, Band 1-4, Heidelberg: Roland Asanger Verlag.

Binswanger, Ludwig (2004): "Insanity as Life-Historical Phenomenon and as Mental Disease: the Case of Ilse" i Rollo May (red.), Existence, Oxford: Aronson. 
Cooper, Mick (2011): Eksistentielle terapier, København: Dansk Psykologisk Forlag.

Deurzen, Emmy van (2006 [1987]): Eksistentiel samtale og terapi, København: Hans Reitzels Forlag.

Deurzen, Emmy van (1999 [1997]): Eksistentielle dimensioner i psykoterapi, København: Hans Reitzels Forlag.

Deurzen, Emmy van \& Claire Arnold Baker (red.) (2005): Existential Perspectives on Human Issues, London: Palgrave.

Deurzen, Emmy van (2009): Psychotherapy and the Quest for Happiness, London: Sage.

Deurzen, Emmy van \& Sarah Young (red.) (2011 [2009]): Eksistentielle perspektiver på supervision, København: Dansk Psykologisk Forlag.

Deurzen, Emmy \& Martin Adams (2012 [2011]): Eksistentiel terapi. En introduktion, København: Hans Reitzels Forlag.

Evans, C. Stephens (1995): Soren Kierkegaard's Christian Psychology, UK: Regent College Pub.

Ferguson, Harvie (1994): Melancholy and the Critique of Modernity, London: Routledge.

Grimault, Marguerite (1965): La mélancolie de Kierkegaard, Paris: Aubier.

Heidegger, Martin (1976): "Nur noch ein Gott kann uns retten”, Der Spiegel, nr. 30, s. 193-219.

Heidegger, Martin (2007): Varen og tid, Aarhus: Klim.

Kierkegaard, Søren (2012): Søren Kierkegaards Skrifter (SKS), København: Gads Forlag.

Kirschenbaum, Howard \& Valerie Henderson (1990): Carl Rogers: Dialogues, London: Constable.

Laing, Ronald D. (2010 [1960]): The Divided Self: An Existential Study in Sanity and Madness, London: Penguin.

Maslow, Abraham (2011 [1954]): Towards a Psychology of Being, US: Wilder Publ.

May, Rollo (1960): Existential Psychology, New York: Random House.

May, Rollo (1983 [1958]): The Discovery of Being, New York: Norton.

May, Rollo, Carl Rogers \& Abraham Maslow (1986): Politics and Innocence: A Humanistic Debate, US: Saybrook.

May, Rollo (1993 [1953]): Man's Search for Himself, London: Souvenir Press.

May, Rollo (1996a [1950]): The Meaning of Anxiety, New York: WW Norton \& Co.

May, Rollo (1996b [1967]): Psychology and the Human Dilemma, New York: WW Norton \& Co.

May, Rollo, Ernest Angel \& Henri E. Ellenberger (red.) (2004 [1958]): Existence, Oxford: Aronson.

Mellergård, Mogens (2000): Epoker i dansk psykiatri, København: Munksgaard. 
Møller, Peter (1846): 'Et besøg i Sorø”, Gaa: Æstethisk Aarbog, s. 144-87.

Norcross, John et al (red.) (2008): History of Psychotherapy, Washington D.C.: American Psychological Association.

Nordentoft, Kresten (1995 [1972]): Kierkegaards psykologi, København: Hans Reitzels Forlag.

Næsgård, Sigurd (1950): En psykoanalyse af Soren Kierkegaard, Odense: Glamsbjerg.

Ostenfeld, I. (1933): Om angst-begrebet $i$ Soren Kierkegaard, København: C. E. Gads Forlag.

Rodolphe, Adam (2005): Lacan et Kierkegaard, Fr.: Presses Universitaires de France.

Rogers, Carl (1942): Counselling and Psychotherapy, Boston: Houghton Mifflin $\&$ Co.

Rogers, Carl \& H. J. Freiberg (1994 [1983]): Freedom to Learn, New Jersey: Merill.

Rogers, Carl (2003 [1951]): Client-Centered Therapy: Its current Practice, Implications and Theory, London: Constable \& Robinson Ltd.

Rogers, Carl (2004 [1961]): On becoming a Person: A Therapists view of Psychotherapy, London: Constable \& Robinson.

Saugstad, Per (1998): Psykologiens historie, Oslo: Gyldendal.

Sørensen, Anders Dræby (2012): 'Integrationen af psykoterapi og læringsmodeller i et praksisudviklingsperspektiv", Slagmark, nr. 64, s. 107-127. 